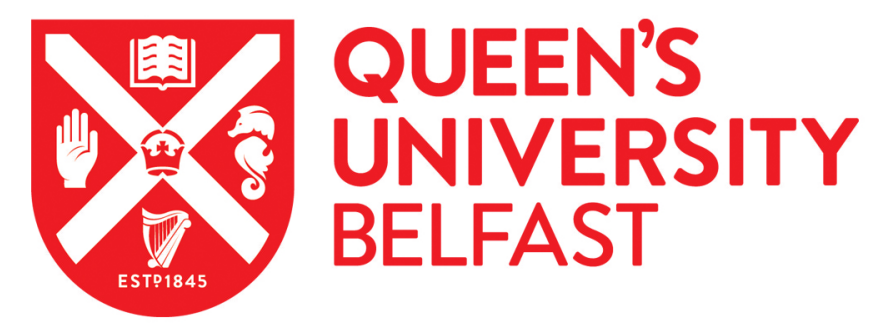

\title{
Higher aqueous levels of resistin and lipocalin-2 indicated worse visual improvement following anti-VEGF therapy in patients with retinal vein occlusion
}

Luo, Y., Wan, J., Luo, C., Liu, H., Zhou, Y., Chen, J., Duan, Y., Ning, X., Zhou, Z., Wang, K., Li, J., Xu, H., \& Chen, Z. (2021). Higher aqueous levels of resistin and lipocalin-2 indicated worse visual improvement following anti-VEGF therapy in patients with retinal vein occlusion. Current eye research, 46(6), 845-854.

https://doi.org/10.1080/02713683.2020.1842462

Published in:

Current eye research

Document Version:

Peer reviewed version

Queen's University Belfast - Research Portal:

Link to publication record in Queen's University Belfast Research Portal

Publisher rights

Copyright 2020 T \& F. This work is made available online in accordance with the publisher's policies. Please refer to any applicable terms of use of the publisher.

\section{General rights}

Copyright for the publications made accessible via the Queen's University Belfast Research Portal is retained by the author(s) and / or other copyright owners and it is a condition of accessing these publications that users recognise and abide by the legal requirements associated with these rights.

\section{Take down policy}

The Research Portal is Queen's institutional repository that provides access to Queen's research output. Every effort has been made to ensure that content in the Research Portal does not infringe any person's rights, or applicable UK laws. If you discover content in the

Research Portal that you believe breaches copyright or violates any law, please contact openaccess@qub.ac.uk. 
2 Higher aqueous levels of resistin and lipocalin-2 indicated worse visual improvement following anti-VEGF therapy in patients with retinal vein occlusion.

Authors: Yong Luo, $\mathrm{MD}^{1,2}$; Jianbo Wan, $\mathrm{MD}^{2}$; Chang Luo, $\mathrm{PhD}^{1,3}$; HengWei Liu, MD ${ }^{1}$; YuFan Zhou, $\mathrm{MD}^{1}$; Juan Chen, $\mathrm{MD}^{2}$; Yiqin Duan, $\mathrm{PhD}^{2}$; Xiangyan Ning, $\mathrm{MD}^{2}$; Zengchao Zhou, $\mathrm{MD}^{2}$; Kehua Wang, MD²; Jun Li, MD²; Heping Xu, MD, PhD ${ }^{1,4,5^{*}}$; and ZhongPing Chen, MD, $\mathrm{PhD}^{1,2^{*}}$

${ }^{1}$ Aier School of Ophthalmology, Central South University, Changsha 410015, Hunan Province, China

${ }^{2}$ Aier Eye Hospital of Changsha, Changsha 410015, Hunan Province, China

${ }^{3}$ Aier Eye Institute, Changsha, Hunan, 410015, China

${ }^{4}$ Aier Institute of Optometry and Vision Science, Changsha, Hunan, 410015, China

${ }^{5}$ The Wellcome-Wolfson Institute for Experimental Medicine, School of Medicine, Dentistry and Biomedical Sciences, Queen's University Belfast, UK

Short title: Resistin/Lipocalin-2 in Retinal Vein Occlusion

\section{* Corresponding authors:}

Heping $\mathrm{Xu}, \mathrm{MD}, \mathrm{PhD}$. The Wellcome-Wolfson Institute for Experimental Medicine, School of Medicine, Dentistry and Biomedical Sciences, Queen's University Belfast, UK, Tel: +86 13327231418; E-mail: heping.xu@qub.ac.uk

ZhongPing Chen, MD, PhD. AIER School of Ophthalmology, Central South University, Changsha 410015, Hunan Province, China, Tel: +86 13755047346, E-mail: chenzhongping@aierchina.com 


\section{Abstract}

Purpose: The aim of this study was to investigate the aqueous humour levels of elastase-2, lactoferrin, lipocalin-2 (LCN-2), resistin and thrombospondin-1 (TSP-1) in patients with retinal vein occlusion (RVO) and their relationship with visual prognosis following intravitreal anti-vascular endothelial growth factor (VEGF) therapy.

Materials and Methods: 52 RVO patients (23 cases of central retinal vein occlusion (CRVO) and 29 cases of branch retinal vein occlusion (BRVO)) and 20 cases of senile cataract were enrolled in this study. All RVO patients underwent fundus examinations before and 6-8 months after intravitreal anti-VEGF treatment. Five milliliters of blood were collected from RVO patients before treatment for the measurement of lipids and coagulation factors. Sixty microliters of aqueous humour were collected during intravitreal injection of anti-VEGF or during cataract surgery. The levels of elastase-2, lactoferrin, LCN-2, resistin and TSP-1 in aqueous humour were determined by Luminex xMAP multiple analysis.

Results: The aqueous levels of resistin and LCN-2 were significantly higher but the level of TSP-1 was significantly lower in RVO patients compared to controls. Further sub-group analysis showed that CRVO patients had significantly higher levels of resistin and LCN-2 than controls. The aqueous levels of resistin and LCN-2 were negatively correlated with visual improvement following anti-VEGF therapy in CRVO but not in BRVO patients. Visual improvement in RVO patients was not associated with blood lipid levels or any of the coagulation factors.

Conclusion: CRVO patients had significantly higher aqueous levels of resistin and LCN-2, which negatively impacted on visual improvement after anti-VEGF therapy.

Keywords: retinal vein occlusion; Lipocalin-2; Resistin; aqueous humour; visual acuity 


\section{Abbreviations:}

2 APTT: activated partial thromboplastin time;

3 BCVA: best-corrected visual acuity;

4 BRVO: branch retinal vein occlusion;

5 CRVO: central retinal vein occlusion;

6 CRT: central retinal thickness;

7 FFA: fundus fluorescein angiography;

8 FIB: fibrinogen;

9 HDL: high-density lipoprotein;

10 LCN-2: lipocalin-2;

11 LDL: low-density lipoprotein;

12 OCT: optical coherence tomography;

13 OCTA: optical coherence tomography

14 angiography
15 PT: prothrombin time;

16 PT-INR: the international normalized ratio

17 of prothrombin time;

18 RVO: retinal vein occlusion;

19 VA: visual acuity;

20 VEGF: vascular endothelial growth factor;

21 TC: cholesterol;

22 TG: triglyceride;

23 TSP-1: thrombospondin-1;

24 TT: thrombin time;

25

26 


\section{Introduction}

Retinal vein occlusion (RVO) is an important sight-threatening disease with the prevalence of $0.3 \%$ to $1.6 \%$ in general population ${ }^{1-3}$. Based on the occlusion site, RVO can be divided into central retinal vein occlusion (CRVO) and branch retinal vein occlusion (BRVO). RVO patients may lose vision due to macular edema at the early stage. As the disease progresses, retinal neovascularisation and vitreous hemorrhage may occur ${ }^{4,5}$. It is believed that macular oedema and neovascularisation in RVO are driven by ischemia-induced excessive expression of vascular endothelial growth factor (VEGF) ${ }^{6,7}$, and intravitreal injection of VEGF inhibitors is currently the standard of care for RVO patients ${ }^{8}$. Howerver, not all RVO patients benefit from the therapy. For example, a recent study reported the proportions of CRVO patiets with at least 15 best-corrected visual acuity (BCVA) letter grain were 47\% for ranibizumsn, $52 \%$ for aflibercept and $45 \%$ for bevacizumab, and $6 \%$ of participants had a losss of at least $30 \mathrm{BCVA}$ letters at 100 weeks ${ }^{9}$. In real-world, the outcome is worse than clinical trials for various reasons such as patients' complianes. For example, the OCEAN study reported only $35 \%$ of RVO patients had a BCVA improvement of $>15$ letters after 2 years of treatment, and $10 \%$ of patients had a deterioration of $>15$ letters ${ }^{10}$. Currently, we do not know why some RVO patients respond well to anti-VEGF therapy, whereas others do not respond to the therapy.

Inflammation is believed to play an important role in the development and progression of RVO ${ }^{11}$. Previous studies have reported higher neutrophil/lymphocyte ratio and platelet/lymphocyte ratio in RVO ${ }^{12-14}$, suggesting abnormal circulating immune cell activation. The activated immune cells may damage vascular endothelial cells, together with platelets and circulating coagulation factors, they may participate in the development of venous thrombosis. Once the occlusion occurs, immune cells infiltrate the retina and accumulate at the sites down-stream to occlusion. Monocytes and neutrophils, in particular, are critically involved in the early phase of inflammatory response. They release various granule contents and enzymes that can escalate inflammatory response and degrade components of the extracellular matrix such as fibrin, fibronectin, collagen, elastin and the glycoproteins of the surrounding tissue including retinal vasculature ${ }^{15,16}$. Higher intraocular levels of inflammatory cytokines such as IL-6 and CCL2 have been detected in RVO patients ${ }^{17-19}$. The RVO retina suffers from both occlusion-mediated ischemia and inflammatory insults. Therefore, in addition to VEGF, 
inflammatory mediators also contribute to retinal pathologies (e.g., macular oedema and retinal neovascularisation) in RVO.

This study aimed to understand the impacts of intraocular immune cell-derived factors on clinical presentations of RVO with macular oedema, in particular, the retinal response to anti-VEGF therapy. To achieve this goal, we measured the aqueous levels of four immune cell-related factors/enzymes including elastase-2, lactoferrin, LCN-2 (also known as neutrophil gelatinase-related lipocalin protein, NGAL), resistin ${ }^{16,20-24}$ and thrombospondin-1 (TSP-1) ${ }^{25}$ in 52 RVO patients (including 23 CRVO, 29 BRVO) and 20 cataract patients. In addition, circulating lipid proteins, including triglyceride (TG), cholesterol (TC), high-density lipoprotein (HDL), low-density lipoprotein (LDL) and coagulation factors (prothrombin time (PT), the international normalized ratio of prothrombin time (PT-INR), thrombin time (TT), activated partial thromboplastin time (APTT) and fibrinogen (FIB)) were also measured in RVO patients. The relationship between the laboratory parameters and clinical features of RVO including response to anti-VEGF therapy was then evaluated. Our results show that intraocular levels of resistin and LCN-2 in RVO, in particular CRVO patients were significantly increased compared to cataract patients; whereas the TSP-1 level was decreased. We further found that higher intraocular levels of resistin and LCN-2 are related to poor visual improvement following anti-VEGF therapy.

\section{Methods}

\subsection{Patients}

Fifty-two patients with RVO (23 cases of CRVO and 29 cases of BRVO) were enrolled in this prospective observational case-control study. The inclusion criteria were patients with RVO diagnosed by fundus stereoscopic examination and fundus fluorescein angiography (FFA), central retinal thickness $(\mathrm{CRT})>300 \mu \mathrm{m}$, and the BCVA was at least 2 lines lower than before disease onset. The exclusion criteria were (1) other retinal diseases; (2) the existence or history of intraocular or systemic inflammatory diseases; (3) the presence or history of cancer, autoimmune diseases, ocular trauma, liver and kidney dysfunction; (4) history of intraocular surgery or laser treatment within 6 months. Twenty patients with senile cataract who needed phacoemulsification served as controls. The exclusion criteria for controls were the same as those of RVO patients. The study was conducted in 
line with the Helsinki Declaration. Informed consent was obtained from each participant and the study was approved by the institutional review committee of Changsha Aier Eye Hospital (Ethical approval number: 201605).

\subsection{Clinical examination}

Each RVO patient underwent a complete ophthalmic examination at the first hospital visit. These include logMAR best-corrected visual acuity (BCVA), slit-lamp examination, intraocular pressure measurement, fundus stereoscopic biomicroscopy, fluorescein fundus angiography (FFA), optical coherence tomography (OCT) and optical coherence tomography angiography (OCTA). All RVO patients were treated with intravitreal anti-VEGF (ranibizumab or Combesette) at the first visit followed by 'injections as pro re nata' (PRN) regime during monthly follow-up visits. Patients were followed up for 6-8 months. The monthly follow-up examinations included visual acuity, intraocular pressure, slit-lamp examination, fundus biomicroscopy. LogMAR visual acuity and central retinal thickness (CRT) were recorded 6 to 8 months after the first treatment. The specific process has been described in the previous research ${ }^{26}$. The improvement of visual acuity was calculated by the $\log$ MAR score of the first visit (before treatment) minus the logMAR score of the last visit, while the change of CRT was calculated by the thickness of the CRT at the first visit minus the thickness of the CRT at the last visit.

Each cataract patient underwent ophthalmic examination before surgery, including BCVA, slit-lamp examination, intraocular pressure measurement, fundus stereoscopic biomicroscopy, and OCT.

\subsection{Blood sample collection}

Fasting blood samples $(7 \mathrm{ml})$ were collected from the upper limb of each RVO participant by a nurse under asepsis conditions. To collect plasma samples, whole blood ( $2 \mathrm{ml})$ were loaded into a blue sterile vacuum blood collection tube containing 3.28\% sodium citrate (Huabo Technology, Heze, Shandong Province, China) and were reversed several times to mix well immediately and left until use. For serum collection, whole blood $(5 \mathrm{ml})$ were loaded into a red sterile vacuum blood collection tube with no anticoagulant (Huabo Technology) and keep it still for 20 minutes. The samples were transported to the biology laboratory of Changsha Aier Eye Hospital at room temperature. The samples were centrifuged at TDZ5-WS low-speed centrifuge (Pingfan Science and Technology, 
Changsha, Hunan Province, China) to extract $2 \mathrm{ml}$ plasma (2 $000 \mathrm{r} / \mathrm{min}, 15 \mathrm{~min}$ ) and $1.5 \mathrm{ml}$ serum ( $2500 \mathrm{r} / \mathrm{min}, 10 \mathrm{~min}$ ) respectively. After the parameters of the automatic analysis instrument were set by professionals, the samples were transferred to their sample trays and were tested immediately (see details below).

\subsection{Measurement of blood sample}

Below coagulation factors were measured in the plasma samples from RVO patients: prothrombin time (PT), international normalized ratio of prothrombin time (PT-INR), thrombin time (TT), activated partial thromboplastin time (APTT) and fibrinogen (FIB) using XL1000 Automatic Coagulation (magnetic bead method) Instrument (ZONCI Technology, Beijing, China), PT Detection Kit ( ZONCI Technology), PT-INR Detection Kit (ZONCI Technology), TT Detection Kit (ZONCI Technology), APTT Detection Kit (ZONCI Technology), and FIB Detection Kit (ZONCI Technology). In addition, below circulating lipid proteins were measured in the serum of RVO patients: triglyceride (TG), cholesterol (TC), high density lipoprotein (HDL) and low density lipoprotein (LDL) by BS-420 Automatic Biochemical Instrument (Mindray Technology, Shenzhen, Guangdong Province, China), TG Oxidase Assay Kit (Mindray Technology), TC Oxidase Assay Kit (Mindray Technology), HDL Oxidase Assay Kit (Mindray Technology), and LDL Oxidase Assay Kit (Mindray Technology).

\subsection{Aqueous sample collection}

Aqueous humour $(60 \mu \mathrm{L})$ was collected during the first intravitreal anti-VEGF injection or during cataract surgery and the procedure was conducted in an ophthalmology surgical operating room. All procedures strictly followed the aseptic operating principles of intraocular surgery. Aqueous samples were kept in sterile Eppendorf and stored at $-80^{\circ} \mathrm{C}$ until laboratory measurements.

\subsection{Laboratory measurement of aqueous humour}

The levels of elastase-2, lactoferrin, LCN-2, resistin and TSP-1 in aqueous humour samples were measured using the MILLIPLEX multiplex assay following manufacture's instructions (Merck Millipore, Burlington, MA, USA). A total of $20 \mu \mathrm{L}$ of aqueous humour from each sample (1:10 dilution) was used in the study. The Median Fluorescent Intensity (MFI) in each well in the plates was measured using a plate reader with the MAGPIX ${ }^{\circledR}$ with xPONENT software (Merck Millipore). 
The concentrations of these proteins in samples were calculated using the spline curve- fitting method. The Minimum Detectable Concentrations (MDCs) of each parameter are as follow: elastase $3 \mathrm{pg} / \mathrm{ml}$, lactoferrin - $195 \mathrm{pg} / \mathrm{ml}, \mathrm{LCN} 2-15 \mathrm{pg} / \mathrm{ml}$, resistin - $4.3 \mathrm{pg} / \mathrm{ml}$, and TSP1 - $69.4 \mathrm{pg} / \mathrm{ml}$.

\subsection{Statistics}

Statistical Package for Social Sciences (SPSS, V.20.0) software was used to analyze the data. The distribution of continuous variables was assessed for normality using the Shapiro-Wilk Test and logarithmic transformation was performed if necessary to achieve normal distribution. The continuous samples of normal distribution of two groups were compared by independent sample ttest. The difference between three groups were analysed using One-way ANOVA followed by Turkey's multiple comparisons test. Covariance analysis was carried out to adjust the parameters after being transformed into normal distribution. For non-normal distribution data that were not suitable for logarithmic transformation, the Mann-Whitney U test was used. The relationship between aqueous humour levels, plasma, serum and clinical parameters were analysed using the Pearson correlation test. $\mathrm{P}<0.05$ was considered statistically significant.

\section{Results}

\subsection{Clinical characteristics}

The clinical data of the participants in each group have been described in our study published previously ${ }^{26}$. In brief, compared with the cataract patients, RVO patients had younger age, higher initial CRT and worse final visit VA(LogMAR). There were no significant differences in gender distribution, hypertension, diabetes, body mass index, smoking habits and initial visual acuity between RVO and controls. Compared with BRVO, CRVO patients had lower VA (initial and final visit) and higher CRT (initial and final visit). There were no significant differences in age, gender distribution, hypertension, diabetes, body mass index and smoking habits between BRVO and CRVO. All RVO patients had macular edema. The duration of macular edema is as follow: 24 (10 CRVO and 14 BRVO) had less than one month, 10 (3 CRVO and 7 BRVO) had 1 2 months, 7 (3 CRVO and 4 BRVO) had 2 3 months, and 11 (7 CRVO, 4 BRVO) had $>3$ months. Colour funds images showed 
that all CRVO eyes had four quadrants of retinal hemorrhage, and 25 out of 29 BRVO patients had single quadrant lesions and 4 had lesions covering $2 \sim 4$ quadrants. FFA was conducted in 22 out of 52 RVO patients, including 15 BRVO and 7 CRVO patients. Reasons for not taking FFA images include allergic to sodium fluorescence and patient refusal. Due to insufficient number of CRVO patients with FFA images, further analysis between "ischemic" and "non-ischemic" CRVO was not conducted.

\subsection{Elastase-2, Lactoferrin, lipocalin-2, resistin, TSP-1 levels in aqueous humour of RVO patients and controls}

Of the 72 aqueous samples, LCN2 was detected in all samples, resistin was detected in 67/72 samples (18 controls, 27 BRVO, and 22 CRVO), lactoferrin was detected in 68/72 samples (19 control, 26 BRVO, and 23 CRVO) and TSP1 was detected in 63/72 samples (18 controls, 24 BRVO, and 21 CRVO), and elastase was detected in 43/72 samples (10 controls, 16 BRVO, and 17 CRVO).

The levels of LCN-2 and resistin in the RVO group were significantly higher than those in the control group; however, the levels of TSP-1 were significantly lower than the control group (Table 1). The level of Elastase-2 and Lactoferrin did not differ significantly between the two groups (Table 1). Further subgroup analysis showed that the level of LCN-2 in CRVO patients was significantly higher than that in controls in Mann-Whitney U test (Table 1). However, the difference disappeared after multiple comparison correction (Tukey's Multiple Comparisons test) or after correction for age in univariate analysis (Table 1). The level of resistin in CRVO was significantly higher than that in BRVO and both were significantly higher than that in cataract patients (Table 1), and the differences remain significant after adjusting for age in univariate analysis. (Table 1). Tukey’s Multiple Comparisons test also confirmed the difference between cataract and BRVO $(\mathrm{P}=0.048)$ and between cataract and CRVO $(\mathrm{P}=0.0006)$, however, the difference between BRVO and CRVO was insignificant $(\mathrm{P}=0.16)$.

Patients with diabetic retinopathy were excluded from this study. However, diabetes patients without diabetic retinopathy were included. Seven out of 52 RVO patients (including 6 BRVO and 1 CRVO) and 6 out of 20 cataract participants had diabetes. There were no significant differences in any of the cytokines between participants with diabetes and those without diabetes in both RVO group of cataract group. 


\subsection{Serum levels of lipids and coagulation factors in RVO patients}

The serum levels of lipids and coagulation factors were measured in RVO but not in cataract patients. We, therefore, compared these factors between CRVO and BRVO patients. Serum levels of TT in CRVO patients were significantly higher than those in BRVO patients (17.00s vs $14.80 \mathrm{~s}, \mathrm{P}=0.036)$. There was no significant difference in levels of HDL $(\mathrm{P}=0.402)$, TG $(\mathrm{P}=0.747), \mathrm{TC}(\mathrm{P}=0.984)$, LDL $(\mathrm{P}=0.39), \mathrm{PT}(\mathrm{P}=0.814), \mathrm{PT}-\mathrm{INR}(\mathrm{P}=0.83)$, APTT $(\mathrm{P}=0.975)$, and FIB $(\mathrm{P}=0.383)$ between CRVO and BRVO groups (Table2).

\subsection{Correlation analysis of serum parameters, aqueous parameters and retinal functional or structural improvement in BRVO patients}

Pearson correlation analysis was conducted to evaluate the possible link between laboratory data from aqueous humour/serum and retinal functional or structural improvement following anti-VEGF therapy in the 29 BRVO patients. Visual improvement in BRVO patients was positively correlated with initial VA $(\operatorname{LogMAR})(\mathrm{r}=0.495 ; \mathrm{P}<0.001)$ and negatively correlated with final visit VA (LogMAR) ( $\mathrm{r}=-0.438, \mathrm{P}<0.05)$. No correlation was observed between visual improvement and any other serum or aqueous humour parameters in BRVO patients (Table 3). Changes in CRT was strongly positively correlated with initial CRT $(\mathrm{r}=0.924, \mathrm{P}<0.001)$, and moderately correlated with initial and finial visit VA ( $\mathrm{r}=0.507, \mathrm{r}=0.515$ respectively, $\mathrm{P}<0.01$ for both). Changes in CRT was not associated with any other parameters, including visual improvement in BRVO patients (Table 3).

The level LCN-2 was positively correlated with elastase-2, TSP-1, and strongly positively correlated with resistin $(\mathrm{r}=0.810, \mathrm{P}<0.01)$ (Table 3$)$. The level of resistin was also positively correlated with TSP-1 ( $\mathrm{r}=0.67, \mathrm{P}<0.01)$, but negatively correlated with LDL $(\mathrm{r}=-0.407, \mathrm{p}=0.035)$ (Table 3$)$.

In the serum, TT was positively correlated with PT $(\mathrm{r}=0.535, \mathrm{P}=0.003)$ and PT-INR ( $\mathrm{r}=0$.627, $\mathrm{P}<0.001)$ but negatively correlated with APTT $(\mathrm{r}=-0.498, \mathrm{P}=0.007)$, FIB $(\mathrm{r}=-0.661, \mathrm{P}<0.001)$. FIB was positively correlated with APTT $(\mathrm{r}=0.402, \mathrm{p}=0.031)$ (Table 3$)$. TC was positively correlated with TG $(\mathrm{r}=0$.454, $\mathrm{P}=0.013)$, HDL $(\mathrm{r}=0.505, \mathrm{P}=0.005)$, LDL $(\mathrm{r}=0$.942, $\mathrm{P}<0.001)$. No correlation was observed between coagulation parameters and lipids/cholesterol levels in BRVO patients (Table 3).

\subsection{Correlation analysis of blood parameters, aqueous parameters and retinal functional or} structural improvement in CRVO patients 
Similar to BRVO patients, visual improvement was negatively correlated with final visit VA (LogMAR); whereas, change in CRT was positively correlated with initial CRT in CRVO patients (Table 4). Interestingly, the aqueous levels of LCN-2 and resistin were negatively correlated with visual improvement in CRVO patients $(\mathrm{r}=-0.492, \mathrm{P}=0.017 ; \mathrm{r}=-0.518, \mathrm{p}=0.014$, respectively) (Table 4). Although, the level of resistin was positively correlated with lactoferrin and the level of lactoferrin was positively correlated with the plasma level of TT, neither lactoferrin nor TT was related to visual improvement in CRVO patients (Table 4). There was no correlation between visual improvement and change in CRT in CRVO patients (Table 4).

Negative correlations were observed between coagulation factors (PT-INR and TT) and blood lipids (TC and LDL) in CRVO patients (Table 4), suggesting that blood levels of total cholesterol and LDL may negatively affect the coagulation pathways in these patients.

\section{Discussion}

In this study, we show that the aqueous levels of resistin and LCN-2 were significantly increased, whereas the TSP-1 levels were significantly reduced in RVO patients compared with cataract controls. In subgroup analysis, the aqueous humour levels of resistin and LCN-2 in CRVO patients were higher than BRVO patients and cataract patients and were negatively correlated with visual improvement after anti-VEGF therapy. Our results suggest that the intraocular levels of resistin and LCN-2 may contribute to the retinal pathology independent of VEGF in CRVO.

Visual impairment in RVO is caused predominately by retinal hemorrhage, macular oedema and neovascularization ${ }^{27,28}$. Intravitreal anti-VEGF therapy reduces vascular leakage to relief RVO-induced macular oedema. Interestingly, we did not observe any significant correlation between visual improvement and change in CRT 6-8 months after anti-VEGF therapy in both BRVO and CRVO patients. This suggests that the central retinal thickness may not always correlate with visual function in RVO. Apart from macular oedema, retinal neuronal death may also contribute to visual impairment. There are at least two reasons that may be accountable for the lack of visual improvement after anti-VEGF therapy in RVO patients: (1) macular oedema may be caused by inflammatory cytokines instead of VEGF; (2) a significant part of visual impairment may be related 
to RVO-mediated retinal neuronal damage. The high intraocular levels of resistin and LCN-2 may contribute to both vascular and neuronal damage in RVO patients.

Resistin is produced predominately by immune cells such as monocytes and macrophages in human and the production is upregulated when immune cells are activated (i.e., during inflammation) ${ }^{29,30}$. Once released, resistin can have diverse biological functions in immune cells and tissue cells, such as the induction of insulin resistance ${ }^{31}$ in obesity and diabetes ${ }^{31}$ and blood vessel damage in cardiovascular diseases ${ }^{33}$. Several studies have shown that resistin can induce thrombotic complications by mediating lipoprotein metabolism in a hypercoagulable environment ${ }^{33,34}$ and the abnormal proliferation of vascular smooth muscle cells in injury and inflammation ${ }^{35-38}$. Resistin is also involved in endothelial nitric oxide (eNO) production, platelet aggregation and adhesion, and endothelium-dependent and independent vasodilation ${ }^{33}$. In this study, higher intraocular level of resistin was positively correlated with thrombin time (before anti-VEGF therapy) and negatively correlated with visual improvement (following anti-VEGF therapy). We did not observe any correlation between intraocular level of resistin and change in CRT. As macular thickness is often related to the level of vascular leakage. Our results suggest that resistin may participate in the thrombotic process but may not be involved in vascular leakage (macular oedema) in CRVO. The metabolism of retinal neurons, in particular, photoreceptors are known to relay, at least partially on the insulin signaling pathway ${ }^{39}$. Whether higher intraocular level resistin in CRVO causes insulin resistance and impairs photoreceptor metabolism remains to be determined.

LCN-2, also known as neutrophil gelatinase-associated lipocalin (NGAL), is a member of the lipocalin superfamily and a pleiotropic mediator of various inflammatory processes ${ }^{40}$. It can be produced by neutrophils as well as many other tissue cells. Neutrophils constitute $40-60 \%$ of white blood cells. In RVO, in particular CRVO, hemorrhage leads to massive immune cell infiltration. The high level of intraocular LCN-2 in CRVO patients observed in this study may originate from infiltrating neutrophils and macrophages. How LCN-2 may contribute to retinal pathology in RVO remains unknown. LCN-2 protects against microbial infection by binding enterobactintype siderophores, thereby preventing bacterial iron acquisition and bacterial growth ${ }^{41,42}$. LCN-2 can also bind to its receptors expressed by human cells (the LCN2 receptor, also known as $24 \mathrm{p} 3 \mathrm{R}$ or SLC22A17, and megalin, also known as low-density lipoprotein receptor-related protein 2, LRP2) 
and the endogenous siderophore 2,5-dihydroxy benzoic acid (2,5-DHBA) ${ }^{43,44}$. Through these interactions, LCN-2 can potentially affect cellular iron metabolism and various inflammatory responses ${ }^{45}$. Furthermore, lipocanin-2 can interact and stabilise pro-matrix metalloproteinase 9 (MMP9), thereby modulating the degradation of extracellular matrix (ECM) components ${ }^{46}$. Higher intraocular level of MMP9 has been observed in RVO patients by us ${ }^{46}$ and others ${ }^{47}$. The fact that higher intraocular level of LCN-2 negatively correlate with visual improvement following anti-VEGF therapy and that the intraocular LCN-2 level was not related to changes in CRT suggests that LCN-2 may impair visual function in CRVO independent of VEGF and vascular leakage. Further mechanistic study will be needed to understand the precise role of LCN-2 in retinal pathology in CRVO.

Another important observation of our study is lower levels of TSP-1 in RVO patients compared with cataract controls. TSP-1 is a potent anti-inflammatory and anti-angiogenic molecule ${ }^{48,49}$. Although we did not detect any correlation between intraocular levels of TSP-1 and visual improvement or change in CRT, insufficient intraocular levels of TSP-1 may partially explain retinal inflammation and angiogenesis in RVO patients.

Our research has a few limitations. First, the sample size is relatively small. Second, the blood tests of lipids and coagulation factors were only conducted in RVO patients but not in control cataract patients. Third, the plasma levels of elastase-2, lactoferrin, LCN-2, resistin and TSP-1 were not measured. Therefore, we do not know whether the plasma levels of these factors were also altered on RVO. Fourth, only basal levels of these parameters were measured in the aqueous humour, therefore we do not know their dynamic changes during treatment. Fifth, FFA images were only collected from a limited number of participants and we were unable to further examine the difference between ischemic and non-ischemic CRVO patients. We were also unable to conduct sub-group analysis of BRVO based on lesion size as only 4 patients had lesions covering 2-4 quadrants and the remaining patients all had lesion covering one quadrant. Finally, the study was conducted in a single center, and the results only reflect the biological characteristics of RVO in the local ethnic population. Multicenter studies are needed to verify the results.

In conclusion, we found that CRVO patients had higher intraocular levels of resistin and LCN-2, which negative impact on visual improvement after anti-VEGF therapy. The aqueous levels of 
resistin and LCN-2 may be useful biomarkers for visual prognosis in CRVO patients. Our study emphasizes the need to further study the role of resistin and LCN-2 in the development and progression of CRVO.

Disclosure statement: The authors declare no conflict of interest.

Funding: This work was supported by the Natural Science Foundation Project of Hunan Province [2018JJ2001; 2018JJ3002], Hunan Science \& Technology Association [2018KX001], National Natural Science Foundation of China [81700827], Science \& Technology Department of Human Province [2018RS3123] and Overseas Talent \& Intelligence Project of Changsha City, and the Research Fund Project of Aier Eye Hospital Group [AM1901D5].

\section{Acknowledgements}

The authors thank the staff at the Changsha Aier Eye Hospital and Aier Eye Institute for their assistance in this research.

\section{Authors contributions}

H.X, Z.P.C and Y.L conceived the study, analyzed data and wrote the manuscript; Z.P.C, Y.L, J.W, H.W.L, Y.F.Z and C.L performed the experiments; X.N, Y.D, Z.Z, J.C, K.W and J.L conducted blood sample analysis. 


\section{References}

1. Mcintosh RL, Mohamed Q, Saw SM, Wong TY. Interventions for branch retinal vein occlusion. An evidence-based systematic review. Ophthalmology 2007:114(5): 835-854.

2. Saw SM, Wong TY, Mcintosh RL, Mohamed Q. Interventions for central retinal vein occlusion: An evidence-based systematic review. Ophthalmology 2007:114(3): 507-519.

3. Lim LL, Cheung N, Wang JJ, Islam FMA, Mitchell P, Saw SM, Aung T, Wong TY. Prevalence and risk factors of retinal vein occlusion in an asian population. Br J Ophthalmol 2008 :92(10): 1316-1319.

4. Wong TY, Scott IU. Retinal-vein occlusion. N Engl J Med 2010:363(22): 2135-2144.

5. Ho M, Liu DTL, Lam DSC, Jonas JB. Retinal vein occlusions from basics to the latest treatment. Retina 2016: 36 : 432-448.

6. Al-Latayfeh M, Silva PS, Sun JK, Aiello LP. Antiangiogenic therapy for ischemic retinopathies. Cold Spring Harb Perspect Med 2012:2(6): a006411.

7. Braithwaite T, Nanji AA, Greenberg PB. Anti-vascular endothelial growth factor for macular edema secondary to central retinal vein occlusion. Cochrane Database Syst Rev 2014:5(5): CD007325.

8. Brown DM, Campochiaro PA, Singh RP, Li Z, Gray S, Saroj N, Rundle AC, Rubio RG, Murahashi WY. Ranibizumab for macular edema following central retinal vein occlusion: Six-month primary end point results of a phase iii study. Ophthalmology 2010:117(6): 1124-1133.e1121.

9. Hykin P, Prevost AT, Vasconcelos JC., Murphy C, Kelly J, Ramu J, Hounsome B, Yang Y, Harding SP, Lotery A, Chakravarthy U, Sivaprasad S. Clinical Effectiveness of Intravitreal Therapy With Ranibizumab vs Aflibercept vs Bevacizumab for Macular Edema Secondary to Central Retinal Vein Occlusion: A Randomized Clinical Trial. JAMA Ophthalmol 2019:137(11):1256-1264.

10. Callizo J, Ziemssen F, Bertelmann T, Feltgen N, Vögeler J, Koch M, Eter N, Liakopoulos S, Schmitz-Valckenberg S, Spital G. Real-world data: Ranibizumab treatment for retinal vein occlusion in the ocean study. Clin Ophthalmol 2019:13:2167-2179.

11. Hu Y, Yu Y, Bu Z, Cun B, Gong Y, Li D, Li J, Lu L, Li G, Yuan L. Increased systemic heparanase in retinal vein occlusion is associated with activation of inflammation and thrombophilia. Retina 2018:2020, 40: 345-349.

12. Zhu DD, Liu X. Neutrophil/lymphocyte ratio and platelet/lymphocyte ratio in branch retinal vein occlusion. J Ophthalmol 2019: 2019:6043612.

13. Dursun A, Ozturk S, Yucel H, Ozec AV, Dursun FG, Toker MI, Erdogan H, Arici MK, Topalkara A. Association of neutrophil/lymphocyte ratio and retinal vein occlusion. Eur J Ophthalmol 2015:25(4): 343-346.

14. Şahin M, Elbey B, Şahin A, Yüksel H, Türkcü FM, Çaça I. Neutrophil-to-lymphocyte ratio and platelet-to-lymphocyte ratio in retinal vein occlusion. Clin Exp Optom 2020: 103(4): 490-494..

15. Si-Tahar M, Pidard D, Balloy V, Moniatte M, Kieffer N, Van Dorsselaer A, Chignard M. Human neutrophil elastase proteolytically activates the platelet integrin alphaiibbeta3 through cleavage of the carboxyl terminus of the alphaiib subunit heavy chain. Involvement in the potentiation of platelet aggregation. J Biol Chem 1997:272(17): 11636-11647.

16. Von Bruhl ML, Stark K, Steinhart A, Chandraratne S, Konrad I, Lorenz M, Khandoga A, Tirniceriu A, Coletti R, Kollnberger M. Monocytes, neutrophils, and platelets cooperate to initiate and propagate venous thrombosis in mice in vivo. Exp Med 2012:209(4): 819-835.

17. Noma H, Yasuda K, Shimura M. Change of cytokines after intravitreal ranibizumab in patients with recurrent branch retinal vein occlusion and macular edema. Eur J Ophthalmol 2019: 1120672119885054.

18. Wen J, Jiang Y, Zheng X, Zhou Y. Six-month changes in cytokine levels after intravitreal bevacizumab injection for diabetic macular oedema and macular oedema due to central retinal vein occlusion. Br J Ophthalmol 
2015:99(10): 1334-1340.

19. Pfister M, Koch FH, Cinatl J, Rothweiler F, Schubert R, Singh P, Ackermann H, Koss MJ. [cytokine determination from vitreous samples in retinal vascular diseases]. Ophthalmologe 2013:110(8): 746-754.

20. Levi M, van der Poll T, Büller HR. Bidirectional relation between inflammation and coagulation. Circulation 2004:109(22): 2698-2704.

21. Furie B, Furie BC. Mechanisms of thrombus formation. N Engl J Med 2008:359(9): 938-949.

22. Saha P, Humphries J, Modarai B, Mattock K, Waltham M, Evans CE, Ahmad A, Patel AS, Premaratne S, Lyons OTA. Leukocytes and the natural history of deep vein thrombosis: Current concepts and future directions. Arterioscler. Thromb Vasc Biol 2011: 31: 506-12.

23. Manfredi AA, Rovere-Querini P, Maugeri N. Dangerous connections: Neutrophils and the phagocytic clearance of activated platelets. Curr. Opin. Hematol 2010:17(1): 3-8.

24. Zapponi KCS, Mazetto BM, Bittar LF, Barnabé A, Santiago-Bassora FD, De Paula EV, Orsi FA, Franco-Penteado CF, Conran N, Annichino-Bizzacchi JM. Increased adhesive properties of neutrophils and inflammatory markers in venous thromboembolism patients with residual vein occlusion and high d-dimer levels. Thromb Res 2014:133(5): 736-742.

25. Sweetwyne MT, Murphy-Ullrich JE. Thrombospondin1 in tissue repair and fibrosis: Tgf- $\beta$-dependent and independent mechanisms. Matrix Biol 2012:31(3): 178-186.

26. Luo Y, Wan J, Luo C, Liu H, Zhou Y, Xu H, Chen Z. Higher aqueous levels of matrix metalloproteinases indicated visual impairment in patients with retina vein occlusion after anti-vegf therapy. Br J Ophthalmol 2019: 315358.

27. Bunce C, Xing W, Wormald R. Causes of blind and partial sight certifications in england and wales: April 2007-march 2008.Eye 2010:24(11): 1692-1699.

28. Fuma S, Nishinaka A, Inoue Y, Tsuruma K, Shimazawa M, Kondo M, Hara H. A pharmacological approach in newly established retinal vein occlusion model. Sci Rep 2017:7:43509.

29. Fain JN, Cheema PS, Bahouth SW, Lloyd Hiler M. Resistin release by human adipose tissue explants in primary culture. Biochem Biophys Res Commun 2003:300(3): 674-678.

30. Patel L, Buckels AC, Kinghorn IJ, Murdock PR, Holbrook JD, Plumpton C, Macphee CH, Smith SA. Resistin is expressed in human macrophages and directly regulated by ppar gamma activators. Biochem Biophys Res Commun 2003:300(2): 472-476.

31. Steppan CM, Bailey ST, Bhat S, Brown EJ, Banerjee RR, Wright CM, Patel HR, Ahima RS, Lazar MA. The hormone resistin links obesity to diabetes. Nature 2001:409: 307-312.

32. Steppan CM, Brown EJ, Wright CM, Bhat S, Banerjee RR, Dai CY, Enders GH, Silberg DG, Wen X, Wu GD. A family of tissue-specific resistin-like molecules. Proc Natl Acad Sci U.S.A 2001:98(2): 502-506.

33. Jamaluddin MS, Weakley SM, Yao Q, Chen C. Resistin: Functional roles and therapeutic considerations for cardiovascular disease. Br J Pharmacol 2012:165(3): 622-632.

34. Fang WQ, Zhang Q, Peng YB, Chen M, Lin XP, Wu JH, Cai CH, Mei YF, Jin H. Resistin level is positively correlated with thrombotic complications in southern chinese metabolic syndrome patients. J Endocrinol Invest 2011:34(2): e36-42.

35. Calabrò P, Cirillo P, Limongelli G, Maddaloni V, Riegler L, Palmieri R, Pacileo G, De Rosa S, Pacileo M, De Palma R. Tissue factor is induced by resistin in human coronary artery endothelial cells by the nf-kB-dependent pathway. Vasc Res 2011, 48: 59-66.

36. Wilcox JN, Smith KM, Schwartz SM, Gordon D. Localization of tissue factor in the normal vessel wall and in the atherosclerotic plaque. Proc Natl Acad Sci U S A:86(8): 2839-2843.

37. Pawashe AB, Golino P, Ambrosio G, Migliaccio F, Ragni M, Pascucci I, Chiariello M, Bach R, Garen A, Konigsberg WK. A monoclonal antibody against rabbit tissue factor inhibits thrombus formation in stenotic injured rabbit carotid 
arteries. Circ Res 1994:74(1): 56-63.

38. Ragni M, Cirillo P, Pascucci I, Scognamiglio A, D’Andrea D, Eramo N, Ezekowitz MD, Pawashe AB, Chiariello M, Golino P. Monoclonal antibody against tissue factor shortens tissue plasminogen activator lysis time and prevents reocclusion in a rabbit model of carotid artery thrombosis.Circulation 1996:93(10): 1913-1918.

39. Rajala A, Rajala RVS. A non-canonical rhodopsin-mediated insulin receptor signaling pathway in retinal photoreceptor neurons. Cell Biol Int 2020:44(4): 1020-1027.

40. Kjeldsen L, Cowland JB, Borregaard N. Human neutrophil gelatinase-associated lipocalin and homologous proteins in rat and mouse. Biochim Biophys Acta 2000:1482(1-2): 272-283.

41. Guo C, Steinberg LK, Cheng M, Song JH, Henderson JP, Gross ML. Site-specific siderocalin binding to ferric and ferric-free enterobactin as revealed by mass spectrometry. ACS Chem Biol 2020:15(5): 1154-1160.

42. Wang $Q$, Li S, Tang X, Liang L, Wang F, Du H. Lipocalin 2 protects against escherichia coli infection by modulating neutrophil and macrophage function. Front Immunol 2019:10(2594).

43. Liu Z, Reba S, Chen WD, Porwal SK, Boom WH, Petersen RB, Rojas R, Viswanathan R, Devireddy L. Regulation of mammalian siderophore 2,5-dhba in the innate immune response to infection. J Exp Med 2014:211(6): 1197-1213.

44. Cabedo Martinez Al, Weinhäupl K, Lee WK, Wolff NA, Storch B, Żerko S, Konrat R, Koźmiński W, Breuker K, Thévenod F et al. Biochemical and structural characterization of the interaction between the siderocalin ngal/lcn2 (neutrophil gelatinase-associated lipocalin/lipocalin 2) and the n-terminal domain of its endocytic receptor slc22a17. J Biol Chem 2016:291(6): 2917-2930.

45. Lu F, Inoue K, Kato J, Minamishima S, Morisaki H. Functions and regulation of lipocalin-2 in gut-origin sepsis: A narrative review. Crit Care 2019:23(1): 269.

46. Rebalka IA, Monaco CMF, Varah NE, Berger T, D'Souza D M, Zhou S, Mak TW, Hawke TJ. Loss of the adipokine lipocalin-2 impairs satellite cell activation and skeletal muscle regeneration. Cell Physiol 2018:315(5): C714-c721.

47. Tuuminen R, Loukovaara S. High intravitreal tgf- $\beta 1$ and $\mathrm{mmp}-9$ levels in eyes with retinal vein occlusion. Eye 2014:28(9): 1095-1099.

48. Zhang X, Lawler J. Thrombospondin-based antiangiogenic therapy. Microvasc Res 2007:74(2): 90-99.

49. Ohmori R, Momiyama Y, Kato R, Taniguchi H, Ogura M, Ayaori M, Nakamura H, Ohsuzu F. Associations between serum resistin levels and insulin resistance, inflammation, and coronary artery disease. Am Coll Cardiol 2005 46(2): 379-380. 
Table1. Aqueous humour levels in RVO patients and controls.

\begin{tabular}{|c|c|c|c|c|c|c|c|c|c|c|c|c|c|c|c|c|}
\hline \multirow[t]{2}{*}{ Variables } & \multicolumn{3}{|c|}{$\operatorname{RVO}(n=52)$} & \multicolumn{3}{|c|}{$\operatorname{BRVO}(n=29)$} & \multicolumn{3}{|c|}{ CRVO $(n=23)$} & \multicolumn{3}{|c|}{ Control $(n=20)$} & \multicolumn{3}{|c|}{ CRVOvs } & \multirow{2}{*}{$\begin{array}{c}\text { CRVOvs } \\
\text { BRVOvs } \\
\text { Control } \\
\text { P-values } \dagger\end{array}$} \\
\hline & $\begin{array}{l}\text { First } \\
\text { quartile }\end{array}$ & Median & $\begin{array}{l}\text { Third } \\
\text { quartile }\end{array}$ & $\begin{array}{l}\text { First } \\
\text { quartile }\end{array}$ & Median & $\begin{array}{l}\text { Third } \\
\text { quartile }\end{array}$ & $\begin{array}{l}\text { First } \\
\text { quartile }\end{array}$ & Median & $\begin{array}{l}\text { Third } \\
\text { quartile }\end{array}$ & $\begin{array}{l}\text { First } \\
\text { quartile }\end{array}$ & Median & $\begin{array}{l}\text { Third } \\
\text { quartile }\end{array}$ & $\begin{array}{c}\text { RVOvs } \\
\text { Control } \\
\text { P-values* }\end{array}$ & $\begin{array}{c}\text { BRVOvs } \\
\text { Control } \\
\text { P-values* }\end{array}$ & $\begin{array}{c}\text { RVOvs } \\
\text { Control } \\
\text { P-values } \dagger\end{array}$ & \\
\hline $\begin{array}{l}\text { Elastase-2 } \\
\text { (pg/ml) }\end{array}$ & 0.00 & 93.92 & 287.01 & 0.00 & 40.03 & 325.99 & 0.00 & 136.53 & 255.79 & 0.00 & 16.30 & 325.99 & 0.511 & $\begin{array}{l}0.813 \ddagger \\
0.323 \S \\
0.502\end{array}$ & 0.93 & $\begin{array}{l}0.709 \ddagger \\
0.510 \S \\
0.376\end{array}$ \\
\hline $\begin{array}{l}\text { Lactoferrin } \\
\text { (pg/ml) }\end{array}$ & 7627.00 & 12236.00 & 30045.25 & 7627.00 & 10898.00 & 17542.00 & 7627.00 & 23879.00 & 40798.00 & 6539.50 & 10196.50 & 20132.00 & 0.382 & $\begin{array}{l}0.927 \$ \\
0.113 \S \\
0.143\end{array}$ & 0.716 & $\begin{array}{l}0.832 \ddagger \\
0.579 \S \\
0.314\end{array}$ \\
\hline $\begin{array}{l}\mathrm{LCN}-2 \\
(\mathrm{pg} / \mathrm{ml})\end{array}$ & 6491.50 & 8476.50 & 11008.75 & 6001.50 & 8219.00 & 11071.00 & 6448.00 & 9113.00 & 11056.00 & 5213.50 & 6802.50 & 8021.25 & 0.042 & $\begin{array}{l}0.104 \$ \\
0.046 \oint \\
0.6\end{array}$ & 0.418 & $\begin{array}{l}0.703 \$ \\
0.104 \S \\
0.596\end{array}$ \\
\hline $\begin{array}{l}\text { Resistin } \\
\text { (pg/ml) }\end{array}$ & 43.69 & 120.42 & 222.60 & 41.43 & 90.97 & 141.23 & 79.67 & 156.92 & 338.41 & 14.75 & 42.04 & 88.80 & 0.001 & $\begin{array}{l}0.021 \ddagger \\
0.001 \S \\
0.03\end{array}$ & $<0.001$ & $\begin{array}{l}<0.001 \ddagger \\
<0.001 \S \\
0.1539\end{array}$ \\
\hline $\begin{array}{l}\text { TSP-1 } \\
\text { (pg/ml) }\end{array}$ & 558.32 & 879.90 & 1354.00 & 460.20 & 879.90 & 1354.00 & 661.38 & 879.90 & 1479.00 & 744.63 & 1573.00 & 3282.25 & 0.048 & $\begin{array}{l}0.073 \ddagger \\
0.091 \S \\
0.619\end{array}$ & 0.471 & $\begin{array}{l}0.561 \ddagger \\
0.081 \S \\
0.47 \uparrow\end{array}$ \\
\hline
\end{tabular}

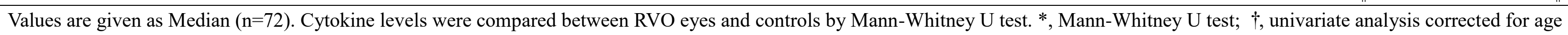
after being transformed to normal distribution; $\ddagger$, Controls vs BRVO; $\S$, Controls vs CRVO; $\mid$, BRVO vs CRVO..

Bold $\mathrm{P}<0.05$ 


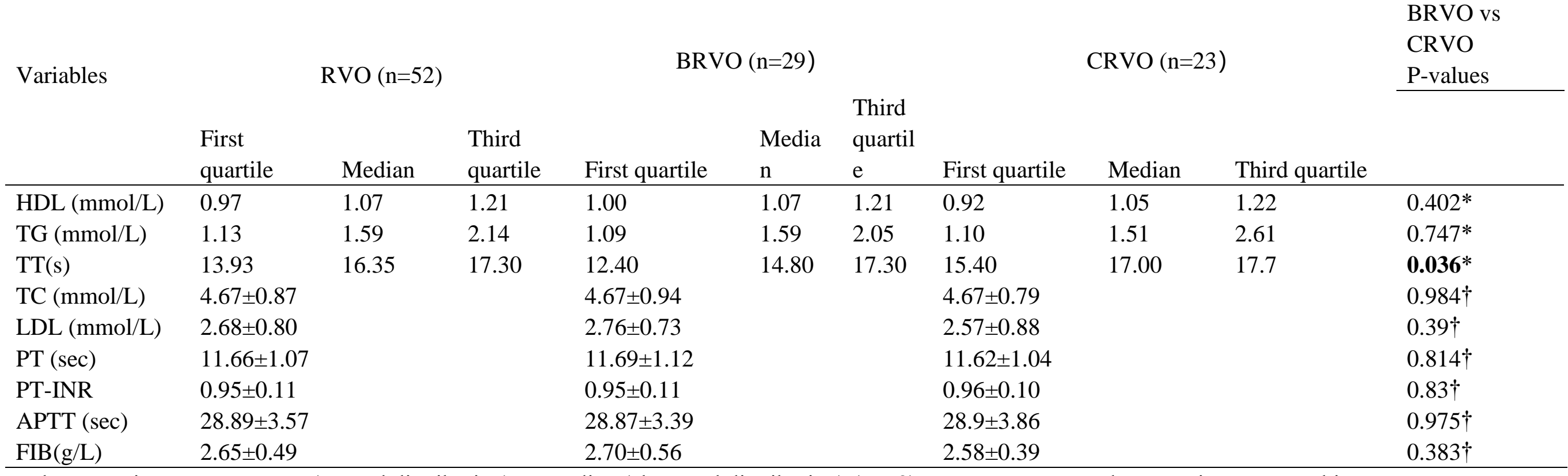

Values are given as Mean \pm SD (normal distribution) or Median (abnormal distribution) (n=52).In row, TT, TG and HDL using Mann-Whitney U test ; PT,

PT-INR, APTT, FIB, TC and LDL using Independent samples t- test.*, Mann-Whitney U test; †, Independent samples t- test. PT - prothrombin time; PT-INR prothrombin time-international normalized ratio; TT - thrombin time; APTT - activated partial thromboplastin time; FIB - fibrinogen; TG - triglycerides; TC -

total cholesterol; HDL - high-density lipoprotein; LDL - low-density lipoprotein. Bold, $\mathrm{P}<0.05$. 
Table3. Correlation between Cytokines and Clinical Data in BRVO patients (n=29).

\begin{tabular}{|c|c|c|c|c|c|c|c|c|c|c|c|c|c|c|c|c|c|c|c|}
\hline Variables & PT & PT-INR & $\mathrm{TT}^{\dagger} \dagger$ & APTT & FIB & $\mathrm{TG}^{\dagger}$ & $\mathrm{TC}$ & $\begin{array}{l}\mathrm{HDL} \\
\dagger\end{array}$ & LDL & $\begin{array}{l}\text { Elastase-2 } \\
\dagger\end{array}$ & Lactoferrin $\dagger$ & $\begin{array}{l}\text { LCN-2 } \\
\dagger\end{array}$ & $\begin{array}{l}\text { Resistin } \\
\dagger\end{array}$ & $\begin{array}{l}\text { TSP-1 } \\
\dagger\end{array}$ & $\begin{array}{l}\text { Initial } \\
\text { VA }\end{array}$ & $\begin{array}{l}\text { Final } \\
\text { visit } \\
\text { VA }\end{array}$ & $\begin{array}{l}\text { Visual } \\
\text { improvement }\end{array}$ & $\begin{array}{l}\text { Initial } \\
\text { CRT }\end{array}$ & $\begin{array}{l}\text { Final } \\
\text { visit } \\
\text { CRT }\end{array}$ \\
\hline
\end{tabular}

\begin{tabular}{|c|c|c|c|c|c|c|c|c|c|c|c|c|c|c|}
\hline PT_INP & $\mathrm{r}$ & $.990 * *$ & 1 & & & & & & & & & & & \\
\hline PI-IINK & $\mathrm{p}$ & $\mathbf{0}$ & 1 & & & & & & & & & & & \\
\hline \multirow{2}{*}{$\mathrm{TT}^{\dagger}$} & $\mathrm{r}$ & $.535 * *$ & $.627 * *$ & 1 & & & & & & & & & & \\
\hline & $\mathrm{p}$ & 0.003 & $\mathbf{0}$ & 7 & & & & & & & & & & \\
\hline \multirow{2}{*}{ APTT } & $\mathrm{r}$ & -0.154 & -0.225 & $-.489 * *$ & & & & & & & & & & \\
\hline & $\mathrm{p}$ & 0.426 & 0.241 & 0.007 & l & & & & & & & & & \\
\hline \multirow{2}{*}{ FIB } & $\mathrm{r}$ & -0.302 & -0.335 & $-.661 * *$ & $.402 *$ & 1 & & & & & & & & \\
\hline & $\mathrm{p}$ & 0.112 & 0.076 & $\mathbf{0}$ & 0.031 & 1 & & & & & & & & \\
\hline \multirow{2}{*}{$\mathrm{TG}^{\dagger}$} & $\mathrm{r}$ & -0.198 & -0.147 & 0.052 & -0.029 & 0.198 & 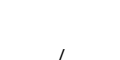 & & & & & & & \\
\hline & $\mathrm{p}$ & 0.302 & 0.446 & 0.789 & 0.883 & 0.303 & 1 & & & & & & & \\
\hline \multirow{2}{*}{$\mathrm{TC}$} & $\mathrm{r}$ & -0.236 & -0.198 & -0.093 & -0.114 & 0.199 & $.454 *$ & 1 & & & & & & \\
\hline & $\mathrm{p}$ & 0.219 & 0.304 & 0.632 & 0.557 & 0.302 & 0.013 & 1 & & & & & & \\
\hline \multirow{2}{*}{$\mathrm{HDL} \dagger$} & $\mathrm{r}$ & -0.249 & -0.264 & -0.263 & 0.042 & 0.136 & -0.23 & $.505 * *$ & & & & & & \\
\hline & $\mathrm{p}$ & 0.193 & 0.166 & 0.167 & 0.83 & 0.48 & 0.231 & 0.005 & 1 & & & & & \\
\hline \multirow{2}{*}{ LDL } & $\mathrm{r}$ & -0.15 & -0.113 & -0.039 & -0.189 & 0.11 & 0.246 & $.942 * *$ & $.415^{*}$ & 1 & & & & \\
\hline & $\mathrm{p}$ & 0.439 & 0.56 & 0.842 & 0.327 & 0.57 & 0.199 & $\mathbf{0}$ & 0.025 & 1 & & & & \\
\hline \multirow{2}{*}{ Elastase- $2 \dagger$} & $\mathrm{r}$ & 0.446 & 0.42 & 0.044 & 0.41 & -0.163 & -0.024 & -0.104 & -0.12 & -0.088 & 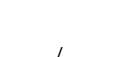 & & & \\
\hline & $\mathrm{p}$ & 0.083 & 0.105 & 0.872 & 0.115 & 0.547 & 0.929 & 0.703 & 0.658 & 0.746 & 1 & & & \\
\hline \multirow{2}{*}{ Lactoferrin $\dagger$} & $\mathrm{r}$ & -0.094 & -0.121 & -0.216 & 0.291 & 0.101 & 0.089 & -0.189 & -0.085 & -0.28 & 0.23 & 1 & & \\
\hline & $\mathrm{p}$ & 0.649 & 0.557 & 0.289 & 0.149 & 0.624 & 0.664 & 0.354 & 0.681 & 0.166 & 0.409 & 1 & & \\
\hline \multirow{2}{*}{$\mathrm{LCN}-2 \dagger$} & $\mathrm{r}$ & 0.061 & 0.085 & 0.221 & 0.335 & -0.122 & 0.192 & 0.071 & 0.078 & 0.002 & $.521 *$ & 0.098 & \multirow{2}{*}{\multicolumn{2}{|c|}{ I }} \\
\hline & $\mathrm{p}$ & 0.752 & 0.66 & 0.248 & 0.075 & 0.529 & 0.318 & 0.713 & 0.689 & 0.991 & 0.038 & 0.633 & & \\
\hline \multirow{2}{*}{ Resistin $\dagger$} & $\mathrm{r}$ & 0.127 & 0.118 & 0.152 & 0.078 & -0.144 & -0.004 & -0.371 & -0.15 & $-.407 *$ & $.538 *$ & 0.142 & $.810 * *$ & \multirow{2}{*}{ I } \\
\hline & $\mathrm{p}$ & 0.526 & 0.558 & 0.45 & 0.699 & 0.473 & 0.985 & 0.057 & 0.455 & 0.035 & 0.032 & 0.488 & $\mathbf{0}$ & \\
\hline \multirow{2}{*}{ TSP-1 ${ }^{\dagger}$} & $\mathrm{r}$ & 0.14 & 0.13 & 0.221 & 0.174 & -0.082 & 0.098 & -0.29 & -0.249 & -0.328 & 0.47 & 0.154 & $.449 *$ & $.671 * *$ \\
\hline & $\mathrm{p}$ & 0.514 & 0.546 & 0.3 & 0.416 & 0.704 & 0.65 & 0.169 & 0.24 & 0.118 & 0.09 & 0.482 & 0.028 & $\mathbf{0}$ \\
\hline
\end{tabular}




\begin{tabular}{|c|c|c|c|c|c|c|c|c|c|c|c|c|c|c|c|c|c|c|c|c|}
\hline \multirow{2}{*}{ Initial VA } & $\mathrm{r}$ & 0.305 & 0.278 & 0.066 & 0.066 & 0.001 & 0.004 & -0.11 & -0.078 & -0.131 & 0.159 & 0.192 & 0.072 & 0.105 & -0.114 & & & & & \\
\hline & $\mathrm{p}$ & 0.107 & 0.144 & 0.733 & 0.734 & 0.997 & 0.982 & 0.572 & 0.686 & 0.499 & 0.555 & 0.347 & 0.711 & 0.603 & 0.595 & 1 & & & & \\
\hline \multirow{2}{*}{ Final visit VA } & $\mathrm{r}$ & $.400 *$ & $.408 *$ & $.385^{*}$ & -0.048 & -0.213 & 0.178 & 0.055 & -0.248 & 0.099 & 0.368 & 0.101 & 0.096 & 0.18 & 0.233 & $.495 * *$ & \multirow{2}{*}{ l } & & & \\
\hline & $\mathrm{p}$ & 0.031 & 0.028 & 0.039 & 0.804 & 0.267 & 0.355 & 0.776 & 0.195 & 0.609 & 0.161 & 0.625 & 0.62 & 0.37 & 0.274 & 0.006 & & & & \\
\hline \multirow{2}{*}{$\begin{array}{c}\text { Visual } \\
\text { improvement }\end{array}$} & $\mathrm{r}$ & -0.064 & -0.101 & -0.298 & 0.114 & 0.203 & -0.165 & -0.166 & 0.154 & -0.229 & -0.209 & 0.106 & -0.017 & -0.062 & -0.333 & $.565 * *$ & $-.438 *$ & \multirow{2}{*}{ I } & & \\
\hline & $\mathrm{p}$ & 0.74 & 0.604 & 0.117 & 0.556 & 0.29 & 0.393 & 0.39 & 0.424 & 0.232 & 0.436 & 0.606 & 0.93 & 0.76 & 0.112 & 0.001 & 0.017 & & & \\
\hline \multirow{2}{*}{ Initial CRT } & $\mathrm{r}$ & 0.34 & 0.345 & 0.179 & -0.349 & -0.16 & -0.005 & 0.124 & -0.12 & 0.231 & 0.135 & -0.069 & -0.062 & 0.272 & 0.058 & 0.259 & $.442 *$ & -0.152 & \multirow{2}{*}{\multicolumn{2}{|c|}{ I }} \\
\hline & $\mathrm{p}$ & 0.071 & 0.067 & 0.352 & 0.063 & 0.406 & 0.979 & 0.521 & 0.536 & 0.228 & 0.619 & 0.738 & 0.749 & 0.17 & 0.789 & 0.175 & 0.016 & 0.432 & & \\
\hline Final visit & $\mathrm{r}$ & 0.178 & 0.187 & 0.09 & $-.370 *$ & -0.157 & -0.072 & 0.107 & -0.076 & 0.232 & 0.101 & -0.017 & -0.227 & 0.076 & 0.068 & $-.392 *$ & 0.051 & $-.454 *$ & $.615^{* * *}$ & 1 \\
\hline CRT & $\mathrm{p}$ & 0.354 & 0.331 & 0.642 & 0.048 & 0.417 & 0.71 & 0.579 & 0.696 & 0.225 & 0.709 & 0.932 & 0.236 & 0.708 & 0.751 & 0.035 & 0.794 & 0.013 & $\mathbf{0}$ & I \\
\hline Change in & $\mathrm{r}$ & 0.329 & 0.331 & 0.175 & -0.247 & -0.12 & 0.029 & 0.1 & -0.11 & 0.17 & 0.105 & -0.077 & 0.034 & 0.297 & 0.038 & $.507 * *$ & $.515 * *$ & 0.035 & $.924 * *$ & 0.266 \\
\hline CRT & $\mathrm{p}$ & 0.081 & 0.08 & 0.363 & 0.196 & 0.535 & 0.882 & 0.607 & 0.571 & 0.379 & 0.699 & 0.709 & 0.859 & 0.132 & 0.862 & 0.005 & 0.004 & 0.857 & $\mathbf{0}$ & 0.163 \\
\hline
\end{tabular}

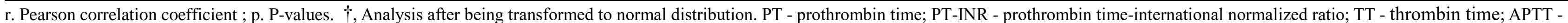

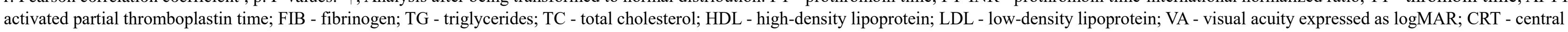
retinal thickness. ${ }^{*} \mathrm{P} \leq 0.05,{ }^{*} \mathrm{p} \leq 0.01$; Bold $\mathrm{P}<0.05$. 


\begin{tabular}{|c|c|c|c|c|c|c|c|c|c|c|c|c|c|c|}
\hline Variable & & PT & PT-INR & $\mathrm{TT}^{\dagger}$ & APTT & FIB & $\mathrm{TG}^{\dagger}$ & $\mathrm{TC}$ & $\mathrm{HDL}^{\dagger}{ }^{\dagger}$ & LDL & $\begin{array}{l}\text { Elastase- } \\
2 \dagger\end{array}$ & $\begin{array}{l}\text { Lactoferri } \\
\mathrm{n} \dagger\end{array}$ & LCN- $2 \dagger$ & $\begin{array}{l}\text { Resistin } \\
\dagger\end{array}$ \\
\hline PT-INR & $\begin{array}{l}\mathrm{r} \\
\mathrm{p}\end{array}$ & $\begin{array}{l}.982 * * \\
0\end{array}$ & 1 & & & & & & & & & & & \\
\hline $\mathrm{TT}_{\dagger}^{\dagger}$ & $\begin{array}{l}\mathrm{r} \\
\mathrm{p}\end{array}$ & $\begin{array}{l}0.309 \\
0.151\end{array}$ & $\begin{array}{l}.442 * \\
0.035\end{array}$ & I & & & & & & & & & & \\
\hline APTT & $\begin{array}{l}\mathrm{r} \\
\mathrm{p}\end{array}$ & $\begin{array}{l}-0.19 \\
0.384\end{array}$ & $\begin{array}{l}-0.278 \\
0.2\end{array}$ & $\begin{array}{l}-.443^{*} \\
0.034\end{array}$ & I & & & & & & & & & \\
\hline FIB & $\begin{array}{l}\mathrm{r} \\
\mathrm{p}\end{array}$ & $\begin{array}{l}-0.257 \\
0.237\end{array}$ & $\begin{array}{l}-0.258 \\
0.235\end{array}$ & $\begin{array}{l}-.441 * \\
0.035\end{array}$ & $\begin{array}{l}-0.123 \\
0.576\end{array}$ & I & & & & & & & & \\
\hline $\mathrm{TG}^{\dagger}$ & $\begin{array}{l}\mathrm{r} \\
\mathrm{p}\end{array}$ & $\begin{array}{l}-0.191 \\
0.382\end{array}$ & $\begin{array}{l}-0.106 \\
0.629\end{array}$ & $\begin{array}{l}0.227 \\
0.298\end{array}$ & $\begin{array}{l}-0.219 \\
0.315\end{array}$ & $\begin{array}{l}0.015 \\
0.947\end{array}$ & I & & & & & & & \\
\hline $\mathrm{TC}$ & $\begin{array}{l}\mathrm{r} \\
\mathrm{p}\end{array}$ & $\begin{array}{l}-0.398 \\
0.067\end{array}$ & $\begin{array}{l}-.426^{*} \\
0.048\end{array}$ & $\begin{array}{l}-.486 * \\
0.022\end{array}$ & $\begin{array}{l}-0.016 \\
0.944\end{array}$ & $\begin{array}{l}.445^{*} \\
0.038\end{array}$ & $\begin{array}{l}0.049 \\
0.828\end{array}$ & I & & & & & & \\
\hline $\mathrm{HDL}^{\dagger}{ }^{\dagger}$ & $\begin{array}{l}\mathrm{r} \\
\mathrm{p}\end{array}$ & $\begin{array}{l}-0.205 \\
0.347\end{array}$ & $\begin{array}{l}-0.271 \\
0.211\end{array}$ & $\begin{array}{l}-0.199 \\
0.362\end{array}$ & $\begin{array}{l}-0.022 \\
0.921\end{array}$ & $\begin{array}{l}0.16 \\
0.465\end{array}$ & $\begin{array}{l}-.619 * * \\
0.002\end{array}$ & $\begin{array}{l}0.211 \\
0.345\end{array}$ & I & & & & & \\
\hline LDL & $\begin{array}{l}\mathrm{r} \\
\mathrm{p}\end{array}$ & $\begin{array}{l}-0.044 \\
0.841\end{array}$ & $\begin{array}{l}-0.127 \\
0.563\end{array}$ & $\begin{array}{l}-.554 * * \\
0.006\end{array}$ & $\begin{array}{l}0.134 \\
0.541\end{array}$ & $\begin{array}{l}0.331 \\
0.123\end{array}$ & $\begin{array}{l}-0.238 \\
0.274\end{array}$ & $\begin{array}{l}.828 * * \\
0\end{array}$ & $\begin{array}{l}0.132 \\
0.547\end{array}$ & I & & & & \\
\hline Elastase- $2 \dagger$ & $\begin{array}{l}\mathrm{r} \\
\mathrm{p}\end{array}$ & $\begin{array}{l}-0.127 \\
0.627\end{array}$ & $\begin{array}{l}-0.105 \\
0.689\end{array}$ & $\begin{array}{l}0.119 \\
0.649\end{array}$ & $\begin{array}{l}0.053 \\
0.839\end{array}$ & $\begin{array}{l}-0.191 \\
0.463\end{array}$ & $\begin{array}{l}0.157 \\
0.548\end{array}$ & $\begin{array}{l}-0.273 \\
0.289\end{array}$ & $\begin{array}{l}0.129 \\
0.621\end{array}$ & $\begin{array}{l}-.545^{*} \\
0.024\end{array}$ & I & & & \\
\hline $\begin{array}{l}\text { Lactoferrin } \\
\dagger\end{array}$ & $\begin{array}{l}\mathrm{r} \\
\mathrm{p}\end{array}$ & $\begin{array}{l}0.083 \\
0.707\end{array}$ & $\begin{array}{l}0.114 \\
0.605\end{array}$ & $\begin{array}{l}.525^{*} \\
0.01\end{array}$ & $\begin{array}{l}-0.07 \\
0.75\end{array}$ & $\begin{array}{l}-0.382 \\
0.072\end{array}$ & $\begin{array}{l}-0.027 \\
0.903\end{array}$ & $\begin{array}{l}-0.291 \\
0.189\end{array}$ & $\begin{array}{l}-0.017 \\
0.938\end{array}$ & $\begin{array}{l}-0.221 \\
0.311\end{array}$ & $\begin{array}{l}0.309 \\
0.228\end{array}$ & I & & \\
\hline LCN-2† & $\begin{array}{l}\mathrm{r} \\
\mathrm{p}\end{array}$ & $\begin{array}{l}-0.205 \\
0.348\end{array}$ & $\begin{array}{l}-0.162 \\
0.461\end{array}$ & $\begin{array}{l}0.279 \\
0.197\end{array}$ & $\begin{array}{l}0.03 \\
0.894\end{array}$ & $\begin{array}{l}-0.106 \\
0.631\end{array}$ & $\begin{array}{l}0.321 \\
0.135\end{array}$ & $\begin{array}{l}0.005 \\
0.983\end{array}$ & $\begin{array}{l}-0.133 \\
0.544\end{array}$ & $\begin{array}{l}-0.137 \\
0.532\end{array}$ & $\begin{array}{l}0.195 \\
0.453\end{array}$ & $\begin{array}{l}0.338 \\
0.115\end{array}$ & 1 & \\
\hline Resistin $\dagger$ & $\begin{array}{l}\mathrm{r} \\
\mathrm{p}\end{array}$ & $\begin{array}{l}-0.094 \\
0.679\end{array}$ & $\begin{array}{l}-0.068 \\
0.765\end{array}$ & $\begin{array}{l}.430 * \\
0.046\end{array}$ & $\begin{array}{l}-0.181 \\
0.419\end{array}$ & $\begin{array}{l}-0.319 \\
0.148\end{array}$ & $\begin{array}{l}0.262 \\
0.239\end{array}$ & $\begin{array}{l}0.075 \\
0.746\end{array}$ & $\begin{array}{l}0.007 \\
0.977\end{array}$ & $\begin{array}{l}-0.01 \\
0.964\end{array}$ & $\begin{array}{l}0.246 \\
0.341\end{array}$ & $\begin{array}{l}.511^{*} \\
0.015\end{array}$ & $\begin{array}{l}.706 * * \\
0\end{array}$ & I \\
\hline TSP-1 $\left.\right|^{\dagger}$ & $\mathrm{r}$ & 0.083 & 0.091 & 0.03 & 0.052 & -0.21 & 0.137 & 0.058 & -0.103 & 0.106 & 0.203 & -0.218 & -0.286 & -0.153 \\
\hline
\end{tabular}




\begin{tabular}{|c|c|c|c|c|c|c|c|c|c|c|c|c|c|c|c|c|c|c|c|c|}
\hline \multirow{3}{*}{ Initial VA } & $\mathrm{p}$ & 0.721 & 0.694 & 0.899 & 0.822 & 0.362 & 0.553 & 0.809 & 0.656 & 0.648 & 0.469 & 0.342 & 0.209 & 0.521 & & \multirow{3}{*}{ I } & & & & \\
\hline & $\mathrm{r}$ & -0.406 & $-.428^{*}$ & -0.301 & 0.174 & $.505^{*}$ & -0.139 & 0.15 & 0.112 & 0.159 & -0.286 & 0.12 & -0.119 & -0.325 & -0.276 & & & & & \\
\hline & $\mathrm{p}$ & 0.055 & 0.041 & 0.163 & 0.429 & 0.014 & 0.527 & 0.505 & 0.61 & 0.469 & 0.266 & 0.585 & 0.588 & 0.14 & 0.226 & & & & & \\
\hline Final visit & $\mathrm{r}$ & -0.368 & -0.347 & -0.092 & -0.094 & 0.3 & 0.019 & 0.103 & 0.109 & 0.082 & -0.22 & 0.166 & 0.287 & 0.134 & -0.25 & $.648 * *$ & \multirow[t]{2}{*}{1} & \multirow{4}{*}{ I } & & \\
\hline VA & $\mathrm{p}$ & 0.084 & 0.105 & 0.676 & 0.67 & 0.165 & 0.931 & 0.65 & 0.62 & 0.71 & 0.396 & 0.448 & 0.184 & 0.551 & 0.273 & 0.001 & & & & \\
\hline $\begin{array}{l}\text { Visual } \\
\text { improveme }\end{array}$ & $\mathrm{r}$ & 0.005 & -0.046 & -0.221 & 0.311 & 0.191 & -0.179 & 0.041 & -0.011 & 0.075 & -0.066 & -0.073 & $-.492^{*}$ & $-.518^{*}$ & 0.006 & 0.31 & & & & \\
\hline $\mathrm{nt}$ & $\mathrm{p}$ & 0.982 & 0.833 & 0.31 & 0.148 & 0.383 & 0.414 & 0.857 & 0.961 & 0.733 & 0.802 & 0.74 & 0.017 & 0.014 & 0.98 & 0.15 & 0.01 & & & \\
\hline \multirow{2}{*}{ Initial CRT } & $\mathrm{r}$ & -0.142 & -0.127 & 0.108 & -0.258 & -0.156 & 0.376 & -0.04 & 0.019 & -0.155 & 0.258 & 0.005 & 0.209 & 0.254 & 0.122 & 0.078 & 0.342 & -0.339 & \multirow{2}{*}{ I } & \\
\hline & $\mathrm{p}$ & 0.518 & 0.563 & 0.625 & 0.234 & 0.479 & 0.077 & 0.861 & 0.931 & 0.481 & 0.318 & 0.982 & 0.34 & 0.254 & 0.599 & 0.724 & 0.111 & 0.113 & & \\
\hline Final visit & $\mathrm{r}$ & -0.042 & -0.111 & -0.059 & 0.231 & -0.195 & -0.081 & 0.035 & 0.266 & 0.048 & 0.335 & 0.293 & 0.21 & 0.028 & -0.031 & 0.054 & 0.022 & 0.034 & 0.164 & 1 \\
\hline CRT & $\mathrm{p}$ & 0.848 & 0.614 & 0.787 & 0.29 & 0.373 & 0.715 & 0.879 & 0.22 & 0.829 & 0.188 & 0.175 & 0.336 & 0.902 & 0.894 & 0.805 & 0.922 & 0.878 & 0.456 & t \\
\hline Change in & $\mathrm{r}$ & -0.016 & 0.043 & 0.225 & -0.413 & -0.095 & $.419 *$ & -0.109 & -0.177 & -0.197 & -0.063 & -0.173 & 0.045 & 0.186 & 0.138 & -0.068 & 0.169 & -0.287 & $.794 * *$ & -0.406 \\
\hline CRT & $\mathrm{p}$ & 0.941 & 0.846 & 0.303 & 0.05 & 0.665 & 0.046 & 0.628 & 0.42 & 0.367 & 0.81 & 0.43 & 0.84 & 0.406 & 0.55 & 0.757 & 0.442 & 0.185 & o & 0.054 \\
\hline
\end{tabular}

r. Pearson correlation coefficient; p. P-values. $\dagger$, Analysis after being transformed to normal distribution. PT - prothrombin time; PT-INR - prothrombin time-international normalized ratio; TT - thrombin time; APTT -

activated partial thromboplastin time; FIB - fibrinogen; TG - triglycerides; TC - total cholesterol; HDL - high-density lipoprotein; LDL - low-density lipoprotein; VA - visual acuity expressed as logMAR; CRT - central retinal thickness. $* \mathrm{P} \leq 0.05, * * \mathrm{p} \leq 0.01 ;$ Bold $\mathrm{P}<0.05$. 
